\title{
REVIEWARTICLE
}

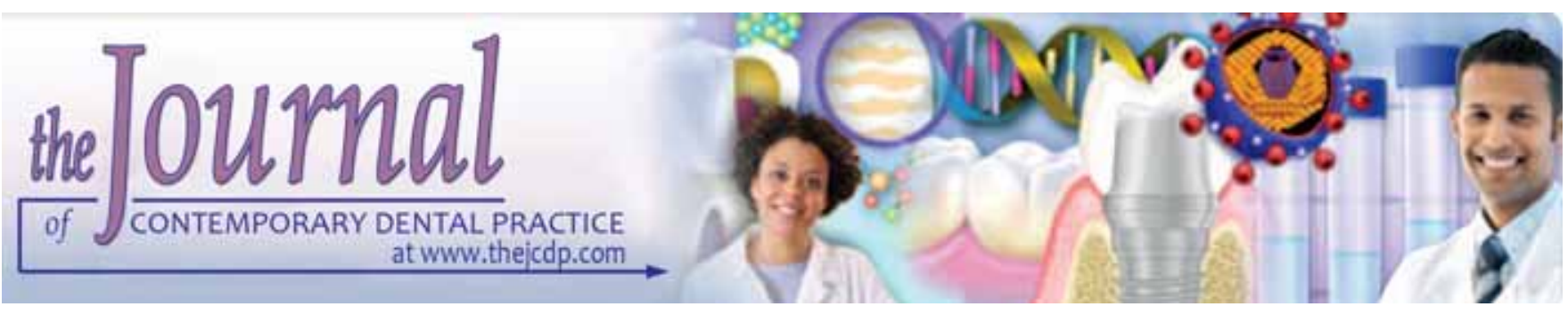

\section{Novel Glass-Ceramics for Dental Restorations}

\section{Sarah Pollington}

\begin{abstract}
Background: There are many different ceramic systems available on the market for dental restorations. Glass-ceramics are a popular choice due to their excellent esthetics and ability to bond to tooth structure allowing a more conservative approach. However, at present, these materials have insufficient strength to be used reliably in posterior regions of the mouth.
\end{abstract}

Purpose: The aim of this review article is to discuss the types of novel glass-ceramic currently be investigated including composition, microstructure and properties.

Conclusion: Current research in glass-ceramics focuses on the quest for a highly esthetic material along with sufficient strength to enable crowns and bridgework to be reliably placed in these areas.

Clinical significance: There is a gap in the market for a machinable resin bonded glass-ceramic with sufficient strength as well as excellent esthetics.

Keywords: Glass-ceramics, Fluormica, Fluorrichterite, Fluorcanasite, Apatite mullite, Lithium disilicate.

How to cite this article: Pollington S. Novel Glass-Ceramics for Dental Restorations. J Contemp Dent Pract 2011;12(1): 60-67.

Source of support: Nil

Conflict of interest: None declared

\section{INTRODUCTION}

All ceramic restorations are becoming increasingly popular for use as dental restorations. They are attractive materials for dental restorations due to a number of different properties: excellent esthetics; low thermal conductivity; high strength; durability; biocompatibility; ease of manufacture; high wear resistance. ${ }^{1-3}$ Developments have occurred over recent years in the form of both new materials and processing methods, such as hot pressing and CAD/ CAM manufacture. In particular, many dental ceramics are glass-ceramic which are partially crystallized glasses that are produced by nucleation and growth of crystals in the glass matrix phase. These final crystals and their distribution can increase the fracture toughness and strength of the material. ${ }^{4}$

Enamel etching with phosphoric acid and ceramic etching with hydrofluoric acid heralded the development of these resin-bonded ceramic restorations. ${ }^{5}$ More recent advancements in material properties and improvements in the fabrication of resin-bonded glass-ceramic restorations now mean that restorations with excellent esthetics can be produced. However, these restorations also have limitations due to the brittle nature of the glass-ceramic along with low strength and fracture toughness. ${ }^{6,7}$ In addition, the presence of numerous surface and internal flaws, which may develop as a result of thermal, chemical or mechanical processes, can act as stress concentrators, and further reduce the strength of these materials. ${ }^{8}$ These stresses can cause cracks to originate from the defect sites, which can propagate and lead to catastrophic failure. ${ }^{8}$ Failure modes include debonding and fracture of the material. ${ }^{9-13}$ Due to the low strength and fracture resistance clinical longevity remains an issue especially in the posterior region of the mouth. ${ }^{14,15}$

Therefore, there is a gap in the market for a glass-ceramic that exhibits excellent esthetics, can be resin bonded to tooth structure, easily fabricated by CAD/CAM technology as well as being very strong and tough.

The main types of novel glass-ceramics that are being researched for potential as dental restorations are as follows: ${ }^{16}$

1. Fluorosilicate glass-ceramics-these materials have good mechanical properties which are dependent upon their highly anisotropic crystalline microstructure. There are two types (1) sheet silicates, e.g. fluormica (2) chain silicates, e.g. fluorrichterite and fluorcanasite

2. Aluminosilicate glass-ceramics - these materials exhibit exceptional stability, good chemical durability and resistance to thermal shock, e.g. apatite mullite 


\begin{tabular}{llll}
\hline & \multicolumn{2}{c}{ Table 1: Novel glass-ceramics for potential dental restorations } \\
\hline Glass-ceramic & Subgroup & Example & Microstructure \\
\hline Fluorosilicate & Sheet silicate & Fluormica & House of cards \\
& Chain silicate & Potassium fluorrichterite & Acicular interlocking \\
Aluminosilicate & - & Fluorcanasite & Acicular interlocking \\
Silicates & - & Apatite mullite & Acicular interlocking \\
& & Lithium disilicate & Dendritic \\
\hline
\end{tabular}

3. Silicate glass-ceramics - these materials are composed primarily of alkali and alkaline silicate crystals, e.g. enstatite. Some compositions are already commercially available, e.g. lithium disilicate.

A summary of these glass-ceramics is shown in Table 1.

\section{FLUOROSILICATE GLASS-CERAMICS}

\section{Sheet Silicates}

Fluormica glass-ceramic, $\mathrm{SiO}_{2}-\mathrm{K}_{2} \mathrm{O}-\mathrm{MgO}-\mathrm{Al}_{2} \mathrm{O}_{3}-\mathrm{ZrO}_{2}$, is a sheet silicate which exhibits excellent properties, such as good cleavage, flexibility and elasticity, which in turn allows machinability, esthetics and chemical durability. ${ }^{17-19}$ During heat treatment, nucleation and growth of tetrasilicate mica crystals occur within the glass. Flexural strength is reported to be in the region of 120 to $150 \mathrm{MPa}$ which when combined with resin bonding should be satisfactory for posterior crowns. ${ }^{20,21}$ The mica crystals strongly affect the optical properties of this glass-ceramic because their refractive index closely matches the refractive index of the glassy matrix allowing for excellent esthetics. But there are disadvantages of these mica glass-ceramics, such as brittleness, easily fractured, low strength and facture toughness. $^{22}$

Fluormica glass-ceramics exhibit a house of cards microstructure and are characterized by interlocking randomly orientated flexible needles or flakes. ${ }^{16,23}$ Machinability of these glass-ceramics relies on this house of cards microstructure and originates in the interlocking pattern of mica platelet crystals, which induces the crack to propagate preferentially along the plane. ${ }^{18,24}$ These crystals also tend to arrest fracture and crack propagation, or cause deflection or branching of cracks. This microstructure also contributes to the relatively high fracture toughness, $2 \mathrm{MPa} \mathrm{m}^{0.5}$ which is also the result of crack blunting, branching and deflection. ${ }^{16}$

However, mica glass-ceramics are not new as dental restorative materials. In 1984, Dicor was the first dental glass-ceramic to be launched. It was developed from a formulation of low thermal expansion ceramic used for cookware by Corning Glass Works and marketed by Dentsply International. Dicor was a micaceous glass- ceramic ( $45 \mathrm{vol} \%$ glass and 55 vol\% crystalline tetrasilicic fluormica), processed by conventional lost waxing and casting techniques. ${ }^{1}$ The clinical applications for this glassceramic were veneers, inlays and crowns in the anterior region only, because its properties proved to be insufficient for posterior restorations.

This material was originally supplied as glass ingots containing a nucleating agent $\left(\mathrm{MgF}_{2}\right)$ that were melted and cast into a refractory mould and subsequently heat treated to allow the growth of the tetrasilicic crystals within the material, which provided the final improved properties. ${ }^{25}$ The restoration was then colored with a thin outer layer of shading porcelain and surface stain to achieve acceptable esthetics. The crystals were responsible for providing the material with strength, resistance to crack propagation, good color stability and optical properties, abrasion resistance, thermal shock resistance and excellent biocompatibility. ${ }^{25}$

Further development of this material resulted in the introduction of Dicor MGC, a machinable glass-ceramic. This was a better quality product, containing $70 \mathrm{vol} \%$ tetrasilicic fluormica, which was crystallized by the manufacturer and provided as CAD/CAM blocks. The mechanical properties of Dicor MGC were similar to Dicor glass-ceramic although it exhibited reduced translucency. ${ }^{26}$

Dicor has since been discontinued due to low tensile strength and the need to color the restorations on the exterior region rather than within the core region. ${ }^{27}$ The survival rate of Dicor in high stress areas was poor in comparison to metal-ceramic restorations. ${ }^{26}$ Its intrinsic mechanical brittleness is responsible for the high failure of these restorations. Generally, the bonding strength of the interlayer ions is the weakest in mica crystal, so the mechanical properties apparently depend on the bonding strength of these interlayer ions. ${ }^{28}$ However, another study has reported a survival rate of $80 \%$ for Dicor restorations over a 14 -year period. ${ }^{29}$ In addition, the fit of Dicor restorations was inferior to metal-ceramic restorations, though still below the 100 $\mu \mathrm{m}$ limit.

A number of investigations have been carried out to improve the properties of mica-based glass-ceramics. Denry et $\mathrm{al}^{30}$ have prepared lithium containing tetrasilicic mica glass-ceramics and found that the presence of lithium 
shortens the crystallization time and decreases the crystallization temperature. Henry and Hill ${ }^{31}$ found that the substitution of lithium for magnesium in potassium fluorphlogopite could reduce glass transition temperature, increase the aspect ratio of fluormica crystals and suppress development of cordierite, whose formation opposes good machinability. It has been reported that fluorophlogopite type $\mathrm{Ca}$ or Ba-based mica, which $\mathrm{Ca}^{2+}$ or $\mathrm{Ba}^{2+}$ took place of alkali ions between interlayers exhibit higher strength. ${ }^{32-34} \mathrm{Li}$ et al ${ }^{28}$ investigated a new fluorophlogopite type Ca mica with lath-shaped crystals. This material demonstrated good strength (228 $\pm 8 \mathrm{MPa}$ ) and was easily machined in less than 12 minutes. Jambi et $\mathrm{al}^{35}$ investigated how the addition of zirconia to mica-based glass composition affected the subsequent transformation of glasses to glass-ceramics upon heat treatment and their mechanical properties, with a view to machining these materials using CAD/CAM technology. They reported that the biaxial flexural strength (BFS) of the glass-ceramics increased significantly with the addition of zirconia to 170 $\mathrm{MPa}$ and that zirconia acted as a nucleating agent for the subsequent crystallization of mica.

To improve the strength of existing fluorine tetrasilicic mica glass-ceramics, Qin et al $^{18}$ developed a new machinable glass-ceramic containing calcium mica. The mechanism of improvement was by exchange of potassium or sodium ions for calcium ions. The microstructure was randomly orientated mica crystals and the strength reported at $210 \pm 14.7 \mathrm{MPa}$. In addition, good machinability was exhibited.

In another study, fluorosilicic mica glass-ceramics were prepared by sintering and different proportions of nano $\mathrm{ZiO}_{2}$ particles (3Y-TZP) were integrated during the process. ${ }^{36}$ With $30 \mathrm{wt} \%$ the bending strength increased to $324 \mathrm{MPa}$ and fracture toughness to $4.2 \mathrm{MPa} \mathrm{m}^{1 / 2}$. The $\mathrm{ZrO}_{2}$ grains were embedded in the lamellar microstructure of the mica. However, machinability may be an issue and would require further investigation.

\section{Chain Silicates}

Chain silicates or inosilicates are polymeric crystals in which single or multiple chains of silica tetrahedra form the structural backbone. Single chain silicates include enstatite, diopside and wollastonite; double chain silicates include fluorrichterite and fluorcanasite and agrellite are examples of multiple chain silicates. ${ }^{37}$

In the late 1970 s, Beall ${ }^{38}$ demonstrated that glassceramics based on modified chain silicate compositions (enstatite, potassium fluorrichterite and canasite) have particularly high fracture toughness (3-5 $\mathrm{MPa} \mathrm{m}^{1 / 2}$ ) and bending strength (200-300 $\mathrm{MPa})$. Enstatite $\left(\mathrm{MgSiO}_{3}\right)$ is a single chain silicate and fine grained, tough glass-ceramics have been produced, based on the enstatite systems. Beall ${ }^{38}$ has fabricated enstatite glass-ceramics with fracture toughness of 3.5 to $4.6 \mathrm{MPa} \mathrm{m}{ }^{1 / 2}$. Enstatite also exhibits high strength combined with refractoriness and high creep resistance. ${ }^{39}$ It undergoes martensitic transformation to the monoclinic phase clinoenstatite. This transformation develops polysynthetic twinning which is responsible for unusually high fracture toughness and reduced facture propagation. ${ }^{40}$ However, enstatite would appear to be unsuitable as a restorative material due to its relatively high ceramming temperature of $1400^{\circ} \mathrm{C}$. Enstatite has been produced at a lower temperature but resulted in poor stability. $^{41}$

\section{Potassium Fluorrichterite}

Potassium fluorrichterite $\left(\mathrm{SiO}_{2}-\mathrm{MgO}-\mathrm{CaO}-\mathrm{Na}_{2} \mathrm{O}-\mathrm{K}_{2} \mathrm{O}-\mathrm{F}\right)$ is a double chain silicate and a member of the amphibole mineral group. These glass-ceramics exhibit a chain structure with randomly orientated needle, like crystals, which promote multiple crack deflections when fractured. ${ }^{16,42}$ They are characterized by high strength and excellent chemical durability and resistance to slow crack growth. ${ }^{43}$ Fluorrichterite glass-ceramics have a high fracture toughness of approximately $3 \mathrm{MPa} \mathrm{m}^{1 / 2}$, bending strength $150 \mathrm{MPa}$ and, if a glaze is applied, the strength increases to $200 \mathrm{MPa} .{ }^{16,38,42,44}$ In addition, the presence of potassium reduces the amount of sagging during the crystallization heat treatment. The high fracture toughness of potassium fluorrichterite is due to the random acicular orientation of the interlocked crystals.

Other desirable properties include optical translucency and a high resistance to thermal shock. ${ }^{16,45}$ It has been demonstrated in thermal shock experiments that no defects occurred following thermal shocking from 170 to $8^{\circ} \mathrm{C}$. It is the needle-like crystal morphology of the material which is responsible for the favorable properties, such as high fracture toughness and machinability. Fluorrichterite is manufactured as high performance institutional tableware and mugs for the retail Corelle line, originally by Corning Inc and now by World Kitchen Inc. ${ }^{23,45}$

These fluorrichterite glass-ceramics have potential for use in restorative dentistry and biomedical applications, because they can be cast to shape and following ceramming exhibit high biaxial flexural strength and fracture toughness. ${ }^{46}$ Work by Denry and Holloway ${ }^{43}$ has shown that these glass-ceramics have the potential for hot pressing. They also reported that increasing amounts of magnesium in the glass-ceramic composition led to a dual microstructure 
consisting of tetrasilicic mica platelets and potassium fluorrichterite prismatic crystals. ${ }^{42}$ It was found that this type of microstructure impeded crack propagation by increasing the number of crack deflections and thus increased the fracture toughness of the material. In addition, increasing the sodium content of the composition led to a decrease in the glass transition, crystallization temperatures and onset of melting while retaining a dual structure composed of fluorrichterite and mica. ${ }^{43}$ This allows the glass-ceramic to be hot pressed at a lower temperature. More recent work has shown that the dual microstructure was beneficial to both the strength and reliability of the material. ${ }^{47}$ In this work, the effect of crystallization heat treatment on the microstructure and biaxial flexural strength of fluorrichterite glass-ceramics was investigated and it was found that a two-fold variation occurred depending on the temperature and duration of the crystallization heat treatment. It was thought that this was due to the formation of a low expansion surface layer composed of roedderite which increased the biaxial flexural strength. ${ }^{47,48}$ Additions of aluminum phosphate have also proven to enhance mica nucleation and bioactivity in potassium fluorrichterite glassceramics. ${ }^{48}$ Mirsaneh et $\mathrm{al}^{46}$ investigated the additions of $5 \mathrm{~mol} \% \mathrm{CaF}_{2}$ and also $5 \mathrm{~mol} \% \mathrm{CaO}$ substituted for $\mathrm{MgO}$ in the potassium fluorrichterite formula. It was reported that due to their good mechanical properties and castability, these compositions were considered potential candidates for the fabrication of custom medical devices in restorative dentistry and moderate load-bearing reconstructive bone surgery.

\section{Fluorcanasite}

Canasite, $\mathrm{Ca}_{5} \mathrm{Na}_{4} \mathrm{~K}_{2} \mathrm{Si}_{12} \mathrm{O}_{30}(\mathrm{OH}, \mathrm{F})_{4}$, is a rare mineral which occurs naturally in the Khibiny massif on the Kola Peninsula in North West Russia ${ }^{38}$ and exhibits the most desirable properties out of the chain silicate glass-ceramics. Beall et $\mathrm{al}^{49}$ reported fracture toughness as high as $5.11 \pm 0.22$ MPa $\mathrm{m}^{1 / 2}$ (SENB test), $4.78 \pm 0.34 \mathrm{MPa} \mathrm{m}^{1 / 2}$ (chevron notch test) and $4.88 \pm 0.22 \mathrm{MPa} \mathrm{m}^{1 / 2}$ (short bar technique).

As natural deposits of canasite are rare, fluorcanasite, $\mathrm{Ca}_{5} \mathrm{~K}_{2-3} \mathrm{Na}_{3-4} \mathrm{Si}_{12} \mathrm{O}_{30} \mathrm{~F}_{4}$, has been synthesized from glasses close to its stoichiometry. Thermal processing of glassceramic materials is based on a conventional two-stage heat treatment involving a nucleation stage followed by a growth stage. Nucleation occurs through precipitation of calcium fluoride crystallites with sperulitic growth of canasite upon these nuclei. ${ }^{38,49}$ Addition of excess calcium fluoride to the composition allows improved nucleation and a finer grained glass-ceramic.

The crystal microstructure is anisotropic and comprises randomly orientated, highly acicular interpenetrating blades. ${ }^{50}$ This random orientation is predetermined by the homogeneous nucleation of calcium fluoride crystals in the early stages of the heat treatment process. These canasite glass-ceramics have a high strength and fracture toughness due to this highly interlocking acicular microstructure. ${ }^{16}$ The toughening mechanism is either by the formation of crystallographic cleavage planes or an anisotropic thermal expansion. ${ }^{49,50}$

Being potentially very strong, tough and inexpensive, fluorcanasite shows promise as a metal-free dental restorative material and has been the subject of a number of studies. ${ }^{51-55}$ The glass can be produced from relatively inexpensive ingredients and studies have shown that heating rates and times for the casting and ceramming process can be undertaken in existing dental laboratory furnaces within a working day. ${ }^{53,54}$

One of the key benefits of fluorcanasite is the fracture toughness, which is higher than that of commercially available glass-ceramic systems. Anusavice and Zhang ${ }^{55}$ described a fluorcanasite $\left(\mathrm{Al}_{2} \mathrm{O}_{3}-\mathrm{CaO}-\mathrm{F}-\mathrm{K}_{2} \mathrm{O}-\mathrm{Na}_{2} \mathrm{O}-\mathrm{SiO}_{2}\right)$ glass-ceramic that exhibited fracture toughness values up to $5.0 \mathrm{MPa} \mathrm{m}^{1 / 2}$. Anusavice and Zhang ${ }^{51}$ reported on another base fluorcanasite glass with excess $\mathrm{Al}_{2} \mathrm{O}_{3}$ of attaining a fracture toughness of $2.7 \pm 0.1 \mathrm{MPa} \mathrm{m}^{1 / 2}$. High biaxial flexural strength for a glass-ceramic has also been reported. Johnson et $\mathrm{al}^{53,56}$ reported the biaxial flexural strength of a fluorcanasite based on $60 \mathrm{SiO}_{2}-5 \mathrm{~K}_{2} \mathrm{O}-10 \mathrm{Na}_{2} \mathrm{O}-15 \mathrm{CaO}$ $10 \mathrm{CaF}_{2}$ with excess $\mathrm{CaF}_{2}$ to be 261-280 MPa.

The high chemical solubility of fluorcanasite has been a repeated issue due to its low silica content and inferior acid resistance compared with soda-lime-silica glasses and has been an area of great exploration..$^{51,57,58}$ The ISO standard 6872:2008 states that a core ceramic material must have a chemical solubility less than $2000 \mu \mathrm{g} / \mathrm{cm}^{2}$ and, for a body ceramic that is in direct contact with the oral environment, should be less than $100 \mu \mathrm{g} / \mathrm{cm}^{2}{ }^{2}{ }^{59}$ In an attempt to reduce the chemical solubility of fluorcanasite to an acceptable level for dental restorations, Stokes ${ }^{57}$ investigated the mixed alkali effect, which is a phenomenon of nonlinear properties occurring with the substitution of one alkali metal glass constituent for another. It was found that glass-ceramic with the composition $\mathrm{K}^{7} / \mathrm{Na}^{8}\left(60 \mathrm{SiO}_{2}-7 \mathrm{~K}_{2} \mathrm{O}-8 \mathrm{Na}_{2} \mathrm{O}\right.$ $15 \mathrm{CaO}-10 \mathrm{CaF}_{2}$ ) exhibited the lowest chemical solubility of $650 \mu \mathrm{g} / \mathrm{cm}^{2}$. There was a decrease of $73 \%$ from the original formula, allowing the fluorcanasite to be considered as a core ceramic. However, this composition still showed inferior strength and fracture toughness to the original fluorcanasites produced by van Noort et al. ${ }^{60}$

Reducing the $\mathrm{CaF}_{2}$ content was found to decrease the chemical solubility of fluorcanasite but also resulted in a 
reduction in the mechanical properties of the material. ${ }^{57}$ Likewise, increasing the $\mathrm{CaF}_{2}$ content raised the fracture toughness but at the expense of the chemical durability. Anusavice and Zhang ${ }^{51}$ tested the effect of adding alumina to the frit before casting and results of $2170 \mu \mathrm{g} / \mathrm{cm}^{2}$ (2 wt\% alumina) to $790 \mu \mathrm{g} / \mathrm{cm}^{2}$ (5 wt\% alumina) were achieved. The addition of more alumina (up to $10 \mathrm{wt} \%$ ) significantly reduced the chemical durability of the material, which was attributed to phase separation during heat treatment. Bubb et $\mathrm{al}^{58}$ found that systematic additions of $\mathrm{SiO}_{2}$ and $\mathrm{AlPO}_{4}$ to a fluorcanasite composition resulted in a reduction of the solubility from 2359 to $624 \mu \mathrm{g} / \mathrm{cm}^{2}$ and an increase in biaxial flexural strength from 123 to $222 \mathrm{MPa}$. Anusavice and Zhang ${ }^{12,61}$ investigated the addition of alumina to the batch in an attempt to increase the chemical durability but found in another study, that additions $\geq 2 \mathrm{wt} \%$ resulted in a reduction in mechanical properties.

More recently, Attar ${ }^{62}$ investigated zirconia additions for fluorcanasite compositions with differing $\mathrm{CaF}_{2}$ content. It was found that zirconia inclusions up to $2 \mathrm{wt} \%$ resulted in fracture toughness values of up to $3.2 \mathrm{MPa} \mathrm{m}^{1 / 2}$. It was found that a low fluorine content zirconia-containing fluorcanasite glass-ceramics had significantly higher fracture toughness of 3.4 MPa $\mathrm{m}^{1 / 2}$ and lower chemical solubility of $1400 \pm 700 \mu \mathrm{g} / \mathrm{cm}^{2}$. Zirconia supplements the nucleation role of $\mathrm{CaF}_{2}$, allowing the development of fine grain bodies within a minimum of fluoride. ${ }^{63}$

Various processing methods of fluorcanasite glassceramics have been investigated. van Noort et $\mathrm{al}^{60}$ have demonstrated that fluorcanasite derived from the stoichiometric composition has good castability using the lost wax technique and conventional gold casting investments. Cannavina et al ${ }^{64}$ have shown that the fluorine content is critical to the castability of the material with a higher fluorine content giving better castability. Similarly, Johnson et $\mathrm{al}^{56}$ have shown fluorcanasite glasses to have good castability at $1200^{\circ} \mathrm{C}$. However, Stokes ${ }^{65}$ reported unreliable results for the fabrication of dental castings using the lost wax technique. In addition, it was found that hot pressing was unacceptable due to a coarsening of the grain structure during the pressing process of the fluorcanasite ingots. ${ }^{65} \mathrm{CAD} / \mathrm{CAM}$ machining of blocks of the fluorcanasite glass-ceramic have been successfully performed using the CEREC system. ${ }^{62,65}$ The final coping demonstrated excellent marginal fit with no evidence of chipping or fracture of the ceramic.

More recently, a high silica fluorcanasite composition has been identified with favorable mechanical properties and reduced chemical solubility. ${ }^{52,66}$ It was found that reducing the $\mathrm{CaF}_{2}$ content of the high silica fluorcanasite results in a reduction in chemical solubility along with substantially improved mechanical properties. Fracture toughness of 4.2 MPa ${ }^{1 / 2}$ was reported and chemical solubility was reduced to $700 \mu \mathrm{g} / \mathrm{cm}^{2}$ allowing the material to be used as a core material. This fluorcanasite was found to be machinable using standard CAD/CAM technology and demonstrated a high degree of translucency, indicating that the material has potential for usage in both anterior and posterior regions. In addition, excellent thermal shock properties were demonstrated in comparison to a commercial lithium disilicate glass-ceramic. An appropriate cementation procedure to tooth structure was also evaluated and the fluorcanasite proved to form an adequate and durable bond when bonded adhesively using a composite resin luting system, without the need to acid etch the fitting surface with hydrofluoric acid. ${ }^{52}$

\section{ALUMINOSILICATES}

Apatite mullite glass ceramics belong to the aluminosilicate family of glass-ceramics. There has been considerable interest in these materials and a number of different apatite mullite systems are being investigated as a potential dental restorative material. These are glass ionomer-derived glasses that were first produced by Hill et $\mathrm{al}^{67}$ at the University of Limerick and has been developed since that time in many institutes. ${ }^{56,68-70}$ This glass-ceramic is based on the formula $4.5 \mathrm{SiO}_{2}-0.5 \mathrm{P}_{2} \mathrm{O}_{5}-\mathrm{A}_{12} \mathrm{O}_{3}-\mathrm{xCaO}-\mathrm{xCaF}_{2}$, where $\mathrm{x}$ varies from 0 to 3 . When subjected to a heat treatment, these glass-ceramics were found to crystallize to an apatite phase [fluorapatite- $\mathrm{Ca}_{10}\left(\mathrm{PO}_{4}\right)_{6} \mathrm{~F}_{2}$ ] and a mullite phase $\left(\mathrm{Al}_{6} \mathrm{Si}_{2} \mathrm{O}_{13}\right)$.

These materials exhibit high strength and fracture toughness and values between 2.0 to $2.7 \mathrm{MPa} \mathrm{m}^{0.5}$ have been reported. ${ }^{71}$ It has been proposed that the high strength and fracture toughness arise from the microstructure of needle-shaped apatite crystals and mullite crystals which are interlocking in the microstructure. ${ }^{72}$ The fluorapatite crystals showed a high length to diameter aspect ratio exceeding 50:1 in some cases resulting in a material with high strength and fracture toughness. ${ }^{71}$

During heat treatment, mullite forms following the crystallization of apatite, but anorthite and an aluminium phosphate phase may also form depending on the glass composition. Compositions either side of the apatite stoichiometry give rise to less crystal nucleation than compositions at the apatite stoichiometry and give rise to apatite crystals that coarsen more readily on heat treatment. ${ }^{67,68}$ Biaxial flexural strength and fracture toughness are dependent on the apatite volume fraction and size. 
Calcium fluoride is a major component of most glasses that are used to produce restorations. ${ }^{73}$ Fluorine is critical to apatite formation and, in the absence of fluorine, Ptricalcium phosphate is formed rather than fluorapatite. ${ }^{67}$ Therefore, high fluoride content is necessary to allow crystallization to fluorapatite and apatite mullite. In apatitemullite glass-ceramics, calcium fluoride is thought to have two effects: (1) as a nucleating agent, promoting crystallization of fluoroapatite and mullite and thus strength; (2) as a facilitator of kinetics of crystallization. ${ }^{74}$

The amount of fluoride present is also critical in the formation of these glass-ceramics. If the fluoride content is increased, the glass transition temperature is decreased. Conversely, if the fluoride content is too low, nucleation of crystals and subsequent crystal growth is inhibited. ${ }^{75}$

However, problems have been reported regarding chemical solubility. Fathi et $\mathrm{al}^{75}$ have reported that their apatite mullite glass-ceramic could be used as a core material with an appropriate veneering ceramic but not as stand-alone body ceramic.

Apatite mullite glass-ceramics are reported to show good castability at $1450^{\circ} \mathrm{C}$ using the lost wax technique. ${ }^{56}$ Restorations can be processed quickly and the material can be cast and cerammed within a working day. ${ }^{56}$ In addition, Gorman et $\mathrm{al}^{71,76}$ have demonstrated that these glassceramics can also be processed using the hot pressing technique. They found that further heat treatment after hot pressing apatite mullite resulted in increased crystallization and improved the fracture toughness and strength of the glass-ceramic. A further possible advantage of these glassceramics is their potential for releasing fluoride ions, which inhibit secondary caries. ${ }^{56}$

\section{SILICATE GLASS-CERAMICS}

Lithium disilicate glass-ceramic has been used in dentistry for a number of years, e.g. IPS Empress 2 for hot pressing and E.max CAD for CAD/CAM (Ivoclar Vivadent). Its chemical composition is primarily $65 \mathrm{wt} \%$ lithium disilicate, which represents the main crystalline content. ${ }^{77}$ This material offers high strength of 300 to $400 \mathrm{MPa}$ and fracture toughness of 2.8 to $3.5 \mathrm{MPa} \mathrm{m}^{1 / 2}$ as well as good translucency. ${ }^{45}$ To further improve the esthetic and wear properties, it can be veneered with an apatite-containing glass-ceramic using a sintering process. As with all glassceramics, it is recommended that lithium disilicate restorations be adhesively bonded to etched tooth structure to increase their strength and longevity.

Some recent research has been published on alternative lithium disilicate compositions. Lithium disilicate glassceramics with the composition $\mathrm{LiO}_{2}-\mathrm{SiO}_{2}-\mathrm{Al}_{2} \mathrm{O}_{3}-\mathrm{K}_{2} \mathrm{O}-\mathrm{P}_{2} \mathrm{O}_{5}$ have been under investigation by the incorporation of $\mathrm{ZrO}_{2} \cdot{ }^{78}$ It was found that with increasing amounts of $\mathrm{ZrO}_{2}$, the crystals became smaller. With increasing crystallization time, there was enhanced crystal growth. A highly translucent glass-ceramic with strength of approximately $800 \mathrm{MPa}$ was reported. ElBatal et $\mathrm{al}^{79}$ also have investigated a multicomponent lithium disilicate glassceramic with additions of $\mathrm{Al}_{2} \mathrm{O}_{3}, \mathrm{TiO}_{2}, \mathrm{MgO}$ and $\mathrm{ZrO}_{2}$. This glass-ceramic showed promise as a dental restorative material but further work is required on its mechanical and physical properties.

\section{CONCLUSION}

Glass-ceramics offer many advantages over other allceramic materials for indirect dental restorations. Preparation of tooth structure is more conservative and the restoration can be resin bonded which further increases the strength and fracture toughness. The restorations can be produced by modern methods such as hot pressing and CAD/ CAM technology, which are labor saving and produce a higher quality restoration. Glass-ceramics exhibit good mechanical and physical properties but lack the strength for use in all posterior regions of the mouth.

Glass-ceramics have excellent esthetics in comparison with other all-ceramic materials. Of the currently available machinable ceramics, the high strength materials are mainly zirconia based which are quite opaque and not particularly suited to the anterior region of the mouth. In addition, zirconia is not amenable to resin bonding as the ceramic is unaffected by hydrofluoric acid etching.

Hence, there is a gap in the market for a resin-bonded glass-ceramic with sufficient strength and facture toughness for use in all regions of the mouth. To date, a resin-bonded glass-ceramic has not been developed with sufficient strength to allow fabrication of fixed bridges in the posterior region of the mouth. Therefore, the glass-ceramic of the future should be of exceptional strength without compromising their excellent esthetics.

\section{REFERENCES}

1. Kelly JR, Nishimura I, Campbell SD. Ceramics in dentistry: Historical roots and current perspectives. J Prosthet Dent 1996; 75:18-32.

2. Seha Mirkelam M, Pamuk S, Balkaya MC, Akgungor G. Effect of Tuf-Coat on feldspathic porcelain materials. J Oral Rehabil 2005;32:39-45.

3. Vlasov AS, Karabanova TA. Ceramics and medicine (Review). Glass and Ceramics 1993;50:398-401.

4. Fairhurst CW. Dental ceramics: The state of the science. Adv Dent Res 1992;6:78-81.

5. Horn HR. Porcelain laminate veneers bonded to etched enamel. Dent Clin North Am 1983;27:671-84. 
6. van Dijken JWV, Ormin A, Olofsson AL. Clinical performance of pressed ceramic inlays luted with resin-modified glass ionomer and autopolymerizing resin composite cements. J Prosthet Dent 1999;82:529-35.

7. Morena R, Lockwood PE, Fairhurst CW. Fracture toughness of commercial dental porcelains. Dent Mater 1986;2:58-62.

8. Scherrer SS, Kelly JR, Quinn GD, Xu K. Fracture toughness (KIc) of a dental porcelain determined by fractographic analysis. Dent Mater 1999;15:342-48.

9. Sjogren G, Molin MK, van Dijken JWV. A 5-year clinical evaluation of ceramic inlays (Cerec) cemented with a dual-cured or chemically cured resin composite luting agent. Acta Odontol Scand 1998;56:263-67.

10. Bergman MA. The clinical performance of ceramic inlays: A review. Aust Dent J 1999;44:157-68.

11. Hayashi M, Wilson NHF, Yeung CA, Worthington HV. Systematic review of ceramic inlays. Clin Oral Investig 2003; 7:8-19.

12. Kramer N, Frankenberger R. Clinical performance of bonded leucite-reinforced glass ceramic inlays and onlays after eight years. Dent Mater 2005;21:262-71.

13. Braga RR, Ballester RY, Daronch M. Influence of time and adhesive system on the extrusion shear strength between feldspathic porcelain and bovine dentin. Dent Mater 2000;16: 303-10.

14. Probster L. Compressive strength of two modern all-ceramic crowns. Int J Prosthodont 1992;5:409-14.

15. Clelland NL, Ramirez A, Katsube N et al. Influence of bond quality on failure load of leucite- and lithia disilicate-based ceramics. J Prosthet Dent 2007;97:18-24.

16. Beall GH. Design and properties of glass-ceramics. Annu Rev Mater Sci 1992;22:91-119.

17. Hamzawy EMA, Darwish H. Crystallization of sodium fluormica $\mathrm{Na}(\mathrm{Mg}, \mathrm{Zn}, \mathrm{Ca})\left({ }_{2.5}\right) \mathrm{Si}_{4} \mathrm{O}_{10} \mathrm{~F}_{2}$ glasses. Materials Chemistry and Physics 2001;71:70-75.

18. Qin F, Zheng S, Luo Z et al. Evaluation of machinability and flexural strength of a novel dental machinable glass-ceramic. J of Dent 2009;37:776-80.

19. Beall GH. In: Hench LL, Frieman SW, editors. Advances in nucleation and crystallization in glasses. Westerville, $\mathrm{OH}$ : The American Ceramic Society 1971.

20. Chang JC, Hart DA, Estey AW et al. Tensile bond strengths of five luting agents to two CAD-CAM restorative materials and enamel. J of Prosthet Dent 2003;90:18-23.

21. Rizkalla AS, Jones DW. Mechanical properties of commercial high strength ceramic core materials. Dent Mater 2004; 20: 207-12.

22. Denry IL, Rosenstiel SF. Flexural strength and fracture toughness of Dicor glass-ceramic after embedment modification. J of Dent Res 1993;72:572-76.

23. De Jong BHWS, Adams JW, Aitken BG, Dickinson JE, Fine GJ. Glass Ceramics. Wiley - VCH Verlag GmbH and Co. Weinheim 2005.

24. Xiang Q, Lui Y, Sheng S, et al. Preparation of mica-based glassceramics with needle-like fluorapatite. Dent Mater 2007;23: 251-258.

25. Grossman DG, Walters HV. The chemical durability of dental ceramics. J Dent Res 1989;63:574:234.

26. Anusavice KJ. Philip's science of dental materials (11th ed). Saunders, Philadelphia 2003.

27. Kelsey WP 3rd, Cavel T, Blankenau RJ, et al. 4-year clinical study of castable ceramic crowns. Am J Dent. 1995;8:259-62.
28. Li H, You DQ, Zhou CR et al. Study on machinable glassceramic containing fluorophlogopite for dental CAD/CAM system. J Mater Sci Mater Med. 2006;17:1133-37.

29. Malament KA, Socransky SS. Survival of Dicor glass-ceramic dental restorations over 14 years. Part II: Effect of thickness of Dicor material and design of tooth preparation. J Prosthet Dent 1999;81:662-27.

30. Denry IL, Holloway JA, Tarr LA. Effect of heat treatment on microcrack healing behavior of a machinable dental ceramic. J Biomed Mat Res 1999;48:791-96.

31. Henry J, Hill RG. The influence of lithia content on the properties of fluorophlogopite glass-ceramics. II: Microstructure, hardness and machinability. J Non-Crystal Solids 2003;319:13-30.

32. Uno T, Kasuga T, Nakajima K. High-strength mica-containing glass-ceramics. J Amer Ceram Soc 1991;74:3139-49.

33. Uno T, Kasuga T, Nakayama $\mathrm{S}$ et al. Microstructure of micabased nanocomposite glass-ceramics. J Mat Sci Mat Med 1992; 76:539-341.

34. Hao AS, Wood DJ, Bubb NL, et al. Novel machinable mica based glass ceramics for dental applications. Glass Tech 2004; 45:88-90.

35. Jambi SM, Bubb NL, Wood DJ. Effect of zirconia additions to novel machinable mica based glass-ceramics. J Dent Res 2007;86(Sp Iss A):0389.

36. Yang $\mathrm{H}, \mathrm{Wu} \mathrm{S}, \mathrm{Hu} \mathrm{JA}$ et al. Influence of nano- $\mathrm{ZrO}_{2}$ additive on the bending strength and fracture toughness of fluoro-silicic mica glass-ceramics. Mater and Design 2011;32:1590-93.

37. Holand W, Beall GH. Glass-ceramic technology. American Ceramics Society, Columbus, Ohio, 2002.

38. Beall GH. Chain silicate glass-ceramics. J Non-Cryst Solids 1991;129:163-73.

39. El-Meliegy EAM, Abdel-Hameed SAM. Enstatite-celsian glass ceramic. Mater Characterization 2005;55:28-34.

40. Goeuriot D, Dubois JC, Merle D, Thevenot F, Exbrayat P. Enstatite based ceramics for machinable prosthesis applications. J Eur Ceram Soc 1998;18:2045-56.

41. Huang CM, Kuo DH, Kim YJ, Kriven WM. Phase-stability of chemically derived enstatite $\left(\mathrm{MgSiO}_{3}\right)$ powders. J Am Ceram Soc 1994;77:2625-31.

42. Denry IL, Holloway JA. Effect of magnesium content on the microstructure and crystalline phases of fluoramphibole glassceramics. J Biomed Mater Res (Appl Biomater) 2000;53: 289-96.

43. Denry IL, Holloway JA. Effect of sodium content on the crystallization behaviour of fluoramphibole glass-ceramics. J Biomed Mater Res (Appl Biomater) 2002;63:48-52.

44. Pannhorst W. Glass ceramics: State-of-the-art. J Non-Cryst Solids 1997;219:198-204.

45. Holand W, Rheinberger V, Apel E, van't Hoen C, Holand M, Dommann A, et al. Clinical applications of glass-ceramics in dentistry. J Mater Sci 2006; 17:1037-42.

46. Mirsaneh M, Reaney IM, James PF, Hatton PV. Effect of $\mathrm{CaF}_{2}$ and $\mathrm{CaO}$ substituted for $\mathrm{MgO}$ on the phase evolution and mechanical properties of K-Fluorrichterite glass ceramics. J Am Ceram Soc 2006;89:587-95.

47. Denry IL, Holloway JA. Effect of crystallization heat treatment on the microstructure and biaxial strength of fluorrichterite glassceramics. J Biomed Mater Res Part B: Appl Biomater 2007; 80:454-59.

48. Holloway JA, Denry IL. Effect of aluminum phosphate additions on the crystallization and bioactivity of fluorrichterite glassceramics for biomedical applications. J Am Ceram Soc 2007; 90:2941-46. 
49. Beall GH, Chyung K, Stewart RL, Donaldson KY, Lee HL, Baskaran S, Hasselman DPH. Effect of test method and crack size on the fracture toughness of a chain-silicate glass-ceramic. J Mater Sci 1986;21:2365-72.

50. Likitvanichkul S, Lacourse WC. Effect of fluorine content on crystallization of canasite glass-ceramics. J Mater Sci 1995; 30:6151-55.

51. Anusavice KJ, Zhang NZ. Chemical durability of Dicor and fluorocanasite-based glass-ceramics J Dent Res 1998;77: 1553-59.

52. Pollington S, Fabianelli A, van Noort R. Microtensile bond strength of a resin cement to a novel fluorcanasite glass-ceramic following different surface treatments. Dent Mater 2010;26: 864-72.

53. Johnson A, Shareef MY, van Noort R, Walsh JM. Effect of furnace type and ceramming heat treatment conditions on the biaxial flexural strength of a canasite glass-ceramic. Dent Mater. 2000;16:280-84.

54. Shareef MY, Johnson A, van Noort R. The strength of a canasite glass-ceramic using laboratory procedures. J Dent Res. 1998;77:940:1467.

55. Anusavice KJ, Zhang NZ. Effect of nucleation temperature on toughness and flexure strength of canasite glass-ceramics. J Dent Res 1996;75:395.

56. Johnson A, Shareef MY, Walsh JM, Hatton PV, van Noort R, Hill RG. The effect of casting conditions on the biaxial flexural strength of glass-ceramic materials. Dent Mater 1998;14: 412-16.

57. Stokes CW, van Noort R, Hand RJ. Investigation of the chemical solubility of mixed-alkali fluorcanasite forming glasses. J NonCryst Solids 2006;353:142-49.

58. Bubb NL, Wood DJ, Streit P. Reduction of the solubility of fluorcanasite based glass-ceramics by additions of $\mathrm{SiO}_{2}$ and $\mathrm{AlPO}_{4}$. Glass Tech 2004;45:91-93.

59. ISO 6872 (dental ceramics), International Standards Organisation 2008.

60. van Noort R, Shareef MY, Johnson A, Jamed PF. Properties of a canasite glass-ceramic. J Dent Res 1997;76:21;61.

61. Zhang NZ, Anusavice KJ. Effect of alumina on the strength, fracture toughness and crystal structure of fluorcanasite glassceramics. J Am Ceram Soc 1999;82:2509-13.

62. Attar SG. Fluorcanasite glass-ceramics for dental applications. PhD; University of Sheffield 2005.

63. Beall GH. Alkali, metal, calcium fluorosilicate glass-ceramic articles. United States Patent 4,386,162, 1983.

64. Cannavina G, Johnson A, van Noort R, Hays M. The effect of operator factors on the castability of canasite glass-ceramic. J Dent Res 1998;77:1044.
65. Stokes CW. Canasite glass-ceramics for dental restorations. $\mathrm{PhD}$; University of Sheffield 2003.

66. Pollington S. Evaluation of a novel fluorcanasite glass-ceramic, PhD; University of Sheffield 2008.

67. Hill RG, Patel M, Wood DJ. Preliminary studies on castable apatite-mullite glass-ceramics. In: Bonfeld W, Hastings GW, Tanner KE, editors. Bioceramics 1991;4:79-86.

68. Hill RG, Wood DJ. Apatite-mullite glass ceramics. J Mater Sci Mater Med 1995;6:311-18.

69. Kokubo T, Ito S, Sakka S. Formation of high-strength bioactive glass-ceramic in the system $\mathrm{MgO}-\mathrm{SiO}_{2}-\mathrm{P}_{2} \mathrm{O}_{5}$. J Mater Sci 1986;21:535-40.

70. Rawlings RD. Bioactive glasses and glass-ceramics. Clin Mater 1993;14:155-79.

71. Gorman CM, Hill RG. Heat-pressed glass-ceramics. Part II. Mechanical property evaluation. Dent Mater 2004;20:252-61.

72. Clifford A, Hill RG. Apatite-mullite glass-ceramics. J Non-Cryst Solids 1996;196:346-51.

73. Hill RG, Wilson AD. Some structural aspects of glasses used in ionomer cements. Glass Technol 1988;29:150-57.

74. Fathi H, Johnson A, van Noort R et al. The influence of calcium fluoride $\left(\mathrm{CaF}_{2}\right)$ on biaxial flexural strength of apatite-mullite glass-ceramic materials. Dent Mater 2005;21:846-51.

75. Fathi H, Johnson A, van Noort R et al. The effect of calcium fluoride $\left(\mathrm{CaF}_{2}\right)$ on the chemical solubility of an apatite-mullite glass-ceramic material. Dent Mater 2005:21:551-56.

76. Gorman CM, Hill RG. Heat-pressed ionomer glass-ceramics. Part I: An investigation of flow and microstructure. Dent Mater. 2003:19:320-26.

77. Albakry M, Guazzato M, Swain MV. Biaxial flexural strength, elastic moduli, and x-ray diffraction characterization of three pressable all-ceramic materials. J Prosthet Dent 2003;89:374-80.

78. Apel E, van't Hoen $\mathrm{C}$, Rheinberger $\mathrm{V}$ et al. Influence of $\mathrm{ZrO}_{2}$ on the crystallization and properties of lithium disilicate glassceramics derived from a multi-component system. J Eur Ceram Soc 2007;27:1571-77.

79. ElBatal FH, Azooz MA, Hamdry YM. Preparation and characterization of some multicomponent silicate glasses and their glass-ceramics derivatives for dental applications. Ceramics Int 2008;35:1211-18.

\section{ABOUT THE AUTHOR}

\section{Sarah Pollington \\ (Corresponding Author)}

Lecturer in Restorative Dentistry, Academic Unit of Restorative Dentistry School of Clinical Dentistry, Claremont Crescent, Sheffield S10 2TA UK, Phone: +441142717928, e-mail: s.pollington@sheffield.ac.uk 